\title{
Production and Characterization of Biofuel from Refined Groundnut Oil
}

\author{
A. Jimoh, A.S. Abdulkareem, A.S. Afolabi, J.O. Odigure and U.C. Odili
}

Additional information is available at the end of the chapter

http://dx.doi.org/10.5772/52443

\section{Introduction}

Persistent global energy and fuel crises have shown that fossil fuels are limited source of energy that will ultimately get exhausted [1-3]. Continuous depreciation of the world oil reserves as reported by USEIA (2007) [4] also corroborates the fact that fossil fuels resources like petroleum, coal and natural gas are finite and non-renewable source of energy. Apart from the foreseen shortage of fossil fuels, its rising price and increasing difficulty of paying for them in the next years to come, necessitate the serious urge for alternative resource that will offers reduced emissions, improved biodegradability, improve performance and clean up emissions necessitated continuous research into the development of renewable energy source. Aside the fact that gasoline and diesel are the most widely used fuels coming from fossil fuel [5], it is a known fact now that gasoline contributes to increase hazardous emissions [6] and that diesel with higher carbon numbers contributes to emissions of high particulate matters, high sulphur dioxide and high poly aromatic hydrocarbons [5]. Thus, need for the kind of serious attention being witness in the search for economically viable and environmental friendly renewable fuels like biodiesel.

Biodiesel has been reported to have offered reduced exhaust emissions, improved biodegradability, reduced toxicity and higher cetane rating which can improve performance and clean up emissions [7]. More so, vegetable oil has good resource for the production of biodiesel through transesterification of different types like canola, rapeseed, soybean oil, rapeseed etc [8]. Interesting results have been reported on the production of biodiesel through transesterification of different kinds of vegetable oil from different parts of the world, such include soybean (United State), rapeseed (Europe), oil palm (South-East Asia), jatropha curcus and rice bran oil (India) [9-13]. Besides, esters from vegetable oils have been reported as the best substitutes for diesel because they do not demand any modification in the diesel engine and have a high energetic yield [14]. Fossil fuels dependent countries like 
Nigeria have commenced initiation of policies aimed at re-directing the nation's major energy sources from the finite crude oil to renewable sources. Interestingly, Nigeria is endowed with different renewable energy resources to support the implementation of such policies as reported by $[5,15]$. Literature have shown that vegetable oils are one of the significant renewable feedstock that can provides secure, abundant, cost effective and clean source of energy for developing nations like Nigeria. Common vegetable oil in the country include palm oil, palm kernel oil (PKO), groundnut oil, cottonseed and soybean [5]. Considerable works have been reported in print on biodiesel production from vegetable oils but limited studies were found for vegetable oils common in Nigeria. As at year 2000, limited studies were reported in the literature on production and testing of biodiesel from Nigerian Lauric oils [5]. Recent development only shows some improvement on the exploitation of Nigeria vegetable oils as resources for biodiesel production, such include transesterification of palm kernel oil [5, 16], transesterification of groundnut oil [17-19]. With increasing attention on the use of these oils for biodiesel production, the present study focused more on the optimization of biodiesel production from refined groundnut oil relative to the effects of the major reaction parameters. Groundnut oil has been reported to be among the most consumed vegetable oil and the $13^{\text {th }}$ most important food crop in the world. It is also known to contain a high percentage of unsaturated fatty acid namely oleic and linoleic acid [20] and low free fatty acid value [21].Groundnut seed contain high quality edible oils, protein, and carbohydrate. Globally, 50\% of groundnut produced is used for oil extraction, $37 \%$ for confectionary use and $12 \%$ for seed purpose. The fat in the oil is approximately 50\% monounsaturated, and 30\% polyunsaturated [22]. In comparison, groundnut oil has been reported of having capacity to produce approximately 123 gallons of biodiesel per acre while soybeans yield only 50 gallons [23]. This research work is therefore aimed at optimizing the production of biodiesel from groundnut oil due to its cheapness and availability. This aim can be achieved through the realization of the following objectives;

i. Characterization of the commercially obtained refined groundnut oil by testing for properties like Specific gravity (or density), flash point, kinematic viscosity, acid value, iodine value, sulphur content, moisture or water content etc. Comparison of the results with literature values.

ii. Conversion of the groundnut oil into biodiesel through alkali-based transesterification with methanol using sodium hydroxide $(\mathrm{NaOH})$ as catalyst.

iii. Detailed characterization of the properties of biodiesel produced and comparison of the experimental results obtained with available standards.

iv. Investigation of the effects of temperature, reaction time, catalyst concentration, and mass ratio of methanol to groundnut oil on production yield of the biodiesel.

\subsection{First biodisel}

Walton J., in 1938 recommended that "to get the utmost value from vegetable oils as fuel, it is academically necessary to split off the triglycerides and to run on the residual fatty acid. Practical experiments have not yet been carried out with this; the problems are likely to be much more difficult when using free fatty acids than when using the oils straight from the 
crushing mill. It is obvious that the glycerides have no fuel value and in addition are likely to cause an excess of carbon in comparison with gas oil. Walton's statement pointed in the direction of what is now termed "biodiesel" by recommending the elimination of glycerol from the fuel, although esters was not mentioned. In this connection, some remarkable work performed in Belgium and its former colony, the Belgian Congo (known after its independence for a long time as Zaire), deserves more recognition than it has received. It appears that Belgian patent 422,877, granted on Aug. 31, 1937 to Chavanne G. (University of Brussels, Belgium), constitutes the first report on what is today known as biodiesel. It describes the use of ethyl esters of palm oil (although other oils and methyl esters was mentioned) as diesel fuel. These esters were obtained by acid-catalyzed transesterification of the oil (base catalysis is now more common). This work was of particular interest as it was related to an extensive report published in 1942 on the production and use of palm oil ethyl ester as fuel and the work described the first test of an urban bus operating on biodiesel. A bus fueled with palm oil ethyl ester served the commercial passenger line between Brussels and Louvain (Leuven) in the summer of 1938. The performance of the bus operating on that fuel was reportedly satisfactory. It was noted that the viscosity difference between the esters and conventional diesel fuel was considerably less than that between the parent oil and conventional diesel fuel [24]. The patent also pointed out that the esters are miscible with other fuels and the work also discussed the cetane number $(\mathrm{CN})$ testing of a biodiesel fuel. In the report, the $\mathrm{CN}$ of palm oil ethyl ester was reported as $\sim 83$ (relative to a high-quality standard with CN 70.5, a low-quality standard of CN 18, and diesel fuels with CN of 50 and 57.5). Thus, the reported results agree with modern work reporting relatively high $\mathrm{CN}$ for such biodiesel fuels. A later paper by another author reported the auto-ignition temperature of various alkyl esters of palm oil fatty acids [25]. In more recent times, the use of methyl esters of sunflower oil to reduce the viscosity of vegetable oil was reported at several technical conferences in 1980 and 1981 [26] and marks the beginning of the rediscovery and eventual commercialization of biodiesel. In a similar manner, palm oil was often considered as a source of diesel fuel in the historic studies [27]. Although, the diversity of oils and fats as sources of diesel fuel had been investigated and reported, however, an important aspect again today and striving for energy independence were reflected in other historic investigations [28]. Vegetable oils were also used as emergency fuels and for other purposes during World War II. [29]. For example, Brazil prohibited the export of cottonseed oil so that it could be substituted for imported diesel fuel. Reduced imports of liquid fuel were also reported in Argentina, necessitating the commercial exploitation of vegetable oils [28]. China produced diesel fuel, lubricating oils, gasoline and kerosene, the latter two by a cracking process and other vegetable oils. However, the exigencies of the war caused hasty installation of cracking plants based on fragmentary data. Researchers in India, prompted by the events of World War II, extended their investigations on 10 vegetable oils for development as domestic fuels. Work on vegetable oils as diesel fuel ceased in India when petroleum-based diesel fuel again became easily available at low cost [29]. The Japanese battleship Yamato reportedly used edible refined soya bean oil as bunker fuel [30]. Concerns about the rising use of petroleum fuels and the possibility of resultant fuel shortages in the United States in the years after World War II played a role in inspiring a "dual fuel" project at the Ohio State University, during which cottonseed oil, corn oil and blends with 
conventional diesel fuel were investigated [28]. In modern times, biodiesel is derived or has been reported to be producible from many different sources, including vegetable oils, animal fats, used frying oils and even soap stock [31]. Generally, factors such as geography, climate, and economics determine which vegetable oil is of greatest interest for potential use in biodiesel fuels [32]. Thus, in the United States, soybean oil is considered to be a prime feedstock; in Europe, it is rapeseed (canola) oil, and in tropical countries, it is palm oil. As noted above, different feed stocks were investigated in the historic times. These included palm oil, soybean oil, cottonseed oil, groudnut oil, castor oil and a few less common oils such as babassu and crude raisin seed oil; non-vegetable sources such as industrial tallow and even fish oils were also investigated [26]. Walton, (1938) summarized results on 20 vegetable oils (castor, grapeseed, maize, camelina, pumpkinseed, beechnut, rapeseed, lupin, pea, poppyseed, groudnut, hemp, linseed, chestnut, sunflower seed, palm, olive, soybean, cottonseed, and shea-butter). He also pointed out that "at the moment the source of supply of fuels is in a few hands, the operator has little or no control over prices or qualities and it seems unfortunate that at this date, as with the petrol engine, the engine has to be designed to suit the fuel whereas strictly speaking, the reverse should be the case, that is, obtaining the fuel and refining it to meet the design of an ideal engine" [26]. Although, environmental aspects played virtually no role in promoting the use of vegetable oils as fuel in historic times and no emissions studies were conducted, it is still worthwhile to note some allusions to this subject from that time; (i) "In case further development of vegetable oils as fuel proves practicable, it will simplify the fuel problems of many tropical localities remote from mineral fuel and where the use of wood entails much extra labor and other difficulties connected with the various heating capacities of the wood's use, to say nothing of the risk of indiscriminate deforestation" [33]. (ii) "It might be advisable to mention, at this juncture, that, owing to the altered combustion characteristics, the exhaust with all these oils is invariably quite clean and the characteristic diesel knock is virtually eliminated" [26]. (iii) Observations by other authors included: "invisible" or "slightly smoky" exhausts when running an engine on palm oil [34]; clearer exhaust gases; in the case of use of fish oils as diesel fuels, the exhaust was described as colorless and practically odorless [35]. These visual observations of yesterday have been confirmed in modern times for biodiesel fuel. Numerous recent studies showed that biodiesel fuel reduces most exhaust emissions [28, 31].

\subsection{Production and processing of biodiesel}

The production process of biodiesl involve combination of Alcohol, oil and catalyst in an agitated reactor, approx. at $60^{\circ} \mathrm{C}$ during $1 \mathrm{hr}$. Smaller plants often use batch mode reactors, but larger plants use continuous flows processes involving continuous stirred-tank reactors or plug flow reactors. Biodiesel as a renewable source of energy can be produced from different sources such as lipids, animal fats, vegetable oils and waste vegetable oils (Table 2). It has been reported that the production of biodiesel feedstock is sensitive [27, 36-37]. For instance, the cost of biodiesel can be estimated based on assumption regarding production volume, feedstock and chemical technology, hence feedstock cost comprises a substantial portion of overall biodiesel cost [38, 39]. Production of biodiesel from fats and oils is motivated by the fact that fat and oils contain a glycerol molecule bonded to three fatty acid 
chains, this structure is called a triglyceride and it is the major component of the oil. In general, biodiesel feedstock can be categorized into three groups: Pure vegetable oils (edible or non-edible), animal fats and waste cooking oils. Pure vegetable oil is also utilized for the production of biodiesel due to the fact that the oil composition from vegetable crops is pure [40]. Most liquid plant oils are composed predominantly 18-carbon fatty acids. Oils, which tend to be a liquid at room temperature, tend to have more double-bonds than fats. The major oils of this group are: rapeseed oil (canola), soybean oil, palm oil, sunflower oil, corn oil, groundnut (groudnut) oil, coconut oil, safflower oil, linseed oil, hemp, microalgae oil, Jatropha curcas and Pongamia pinnata [41]. Fats, which tend to be solid at room temperature, can also be used as a feedstock for the production of biodiesel. Fats have shorter carbon fatty acids and tend to have fewer double bonds than oils. These include: sheep tallow, yellow grease, beef, and poultry oil etc. Also used in the production of biodiesel is the waste cooking oils. These are also denominated in literatures as waste fried oils (WFO). It include: used rapeseed oil, used sunflower oil, used soybean oil, used cottonseed oil, used olive oil. The use of waste oil for the production of biodiesel has been identified as economical method, due to the availability of waste cooking oil, however processing and gathering of the waste cooking oil militate against its adoption. Commercial availability of biodiesel is therefore influence by the feedstock availability, which can be achieved in Nigeria through groundnut oil with production rate of 200000 metric tonne per year.

\begin{tabular}{|l|l|l|}
\hline S/N & Chemical Name & Fatty acid Methyl Ester \\
\hline 1 & Chemical Formula Range & $\mathrm{C}_{14}-\mathrm{C}_{24}$ methyl esters \\
\hline 2 & Kinematic Viscosity Range & $3,3-5,2$ \\
\hline 3 & Density Range & $860-894$ \\
\hline 4 & Boiling point Range (K) & $>475$ \\
& Flash Point Range (K) & $430-455$ \\
\hline 5 & Distillation Range (K) & $470-600$ \\
\hline 6 & Vapor Pressure (mmHg at 295K) & $<5$ \\
\hline 7 & Solubility in water & Insoluble in water \\
\hline 8 & Physical appearance & $\begin{array}{l}\text { Light to dark yellow } \\
\text { transparent liquid }\end{array}$ \\
\hline
\end{tabular}

Table 1. Physical Biodiesel Properties (Shay, 1993)

\subsection{Availability and properties of groudnut oil}

Groudnut oil (arachis oil) is an organic material oil derived from groudnuts and it has been noted to have the aroma and taste of its parent legume. It is often used in Chinese, South Asian and Southeast Asian cuisine as much as olive oil is used in the Mediterranean. Groudnut oil is appreciated for its high smoke point relative to many other cooking oils. Its major component fatty acids are oleic acid ( $46.8 \%$ as olein), linoleic acid (33.4\% as linolein), and palmitic acid $(10.0 \%$ as palmitin). The oil also contains some stearic acid, arachidic acid, arachidonic acid, behenic acid, lignoceric acid and other fatty acid [28, 29]. Vegetable oils are 
widely consumed domestically in Nigeria. It is used primarily as a cooking and salad oil. Studies have shown that groundnut oil contains much potassium than sodium and is a good source for calcium, phosphorus and magnesium. It also contains thiamin, vitamin E, selenium, zinc and arginine [42]. Findings have demonstrated that diets high in groudnut oil are as effective as olive oil in preventing heart disease and are heart healthy than very low fat diets [42]. Groudnut oil is of high quality and can withstand higher temperatures without burning or breaking down, has neutral flavour and odour, does not absorb odour from other foods and all these properties thus makes it the most preferred oil in Northern Nigeria [32]. The nutritional values of the groudnut oil are however affected by the method and period of storage, which consequently affect the acceptability of these oils. In Northern Nigeria, women usually do extraction of groudnut oil locally. The women extract the oil to generate substantial income to support their domestic needs with little or no consideration given to groudnut species or the physicochemical properties of the oil. Most women rely on availability rather than quality. Groudnut is mainly grown in the Northern part of Nigeria and the oil is readily available in all parts of Nigeria in large quantities. This is because it has been reported that Nigeria possesses land area of $923,768 \mathrm{~km}^{2}$ arable land constituting about $56 \%$ and vegetation ranging from the Sahel savanna in the extreme North to swamp forest in the south [32]. Therefore most parts of Nigeria are suitable for biofuel crop cultivation. Although an edible oil, its use as a potential feedstock for biodiesel production may not likely compete with other crops grown for food and commercial cooking oil products. Nigerian is ranked $3^{\text {rd }}$ in the world for the production of groundnut oil as shown in Table 3 (USDA, 2009)[43]. The annual production of groundnut in Nigeria is shown in Figure 1. The reduction in the production of groundnut oil between the year 1976 and 1994 can be attributed to the diversion of Nigerian economy from agricultural oil exploitation economy due to discovery of oil in Nigeria. The recent interest (from 1999 till date) in the production of groundnut can be attributed to the Nigerian government commitment to the production of alternative renewable energy sources. Biodiesel has been identified as the alternative energy in the country with groundnut oil as the perfect feedstock for its production without affecting the oil supply for consumption purpose.

\begin{tabular}{|l|l|l|l|l|}
\hline S/No & Vegetable oil & $\begin{array}{l}\text { Production } \\
\text { (billion/year) }\end{array}$ & Animal Fats & $\begin{array}{l}\text { Production } \\
\text { (pounds/year) }\end{array}$ \\
\hline $\mathbf{1 .}$ & Soybean & 18.340 & Edible tallow & 1.625 \\
\hline $\mathbf{2 .}$ & Groudnut & 0.220 & $\begin{array}{l}\text { Inedible } \\
\text { tallow }\end{array}$ & 3.859 \\
\hline $\mathbf{3 .}$ & Cotton seed & 1.000 & $\begin{array}{l}\text { Lard and } \\
\text { Grease }\end{array}$ & 1.306 \\
\hline $\mathbf{4 .}$ & Sunflower & 1.010 & Yellow Grease & 2.633 \\
\hline $\mathbf{5 .}$ & Corn & 2.420 & Poultry Fat & 2.215 \\
\hline $\mathbf{6 .}$ & Others & 0.669 & & \\
\hline & TOTAL & $\mathbf{2 3 . 6 5 9}$ & TOTAL & $\mathbf{1 . 6 3 8}$ \\
\hline
\end{tabular}

Table 2. Annual Oil Productions of Some Biodiesel Sources [44] 


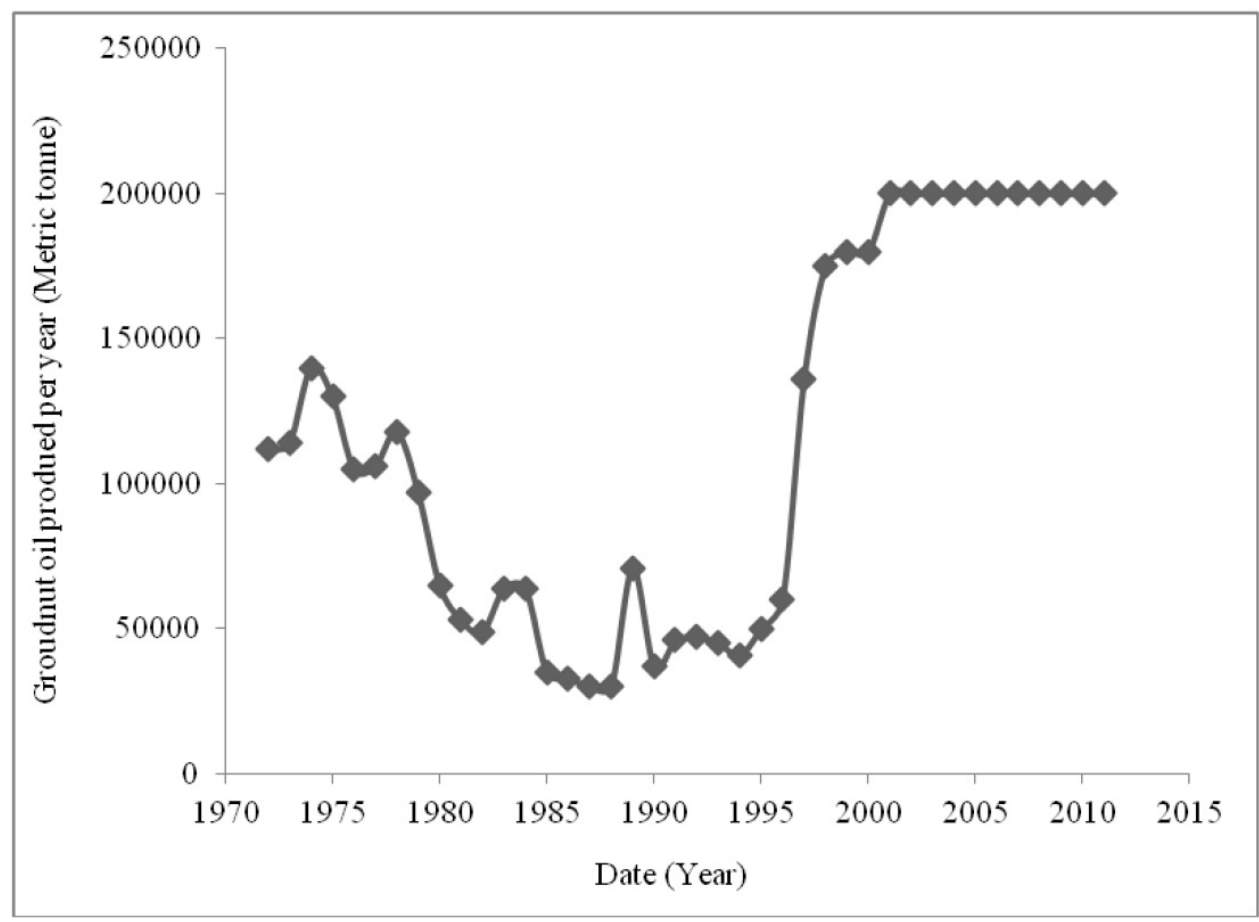

Figure 1. Nigeria's Groundnut (Peanut) Oil Production per Year (United States Department of Agriculture, 2011)

\begin{tabular}{|l|l|c|}
\hline S/No & Country & $\begin{array}{c}\text { Production } \\
\text { Million metric tons }\end{array}$ \\
\hline $\mathbf{1 .}$ & People's Republic of China & 14.30 \\
\hline $\mathbf{2 .}$ & India & 6.25 \\
\hline $\mathbf{3 .}$ & United States & 2.34 \\
\hline $\mathbf{4 .}$ & Nigeria & 1.55 \\
\hline $\mathbf{5 .}$ & Indonesia & 1.25 \\
\hline $\mathbf{6 .}$ & Myanmar & 1.00 \\
\hline $\mathbf{7 .}$ & Sudan & 0.85 \\
\hline $\mathbf{8 .}$ & Senegal & 0.71 \\
\hline $\mathbf{9 .}$ & Argentina & 0.58 \\
\hline $\mathbf{1 0 .}$ & Vietnam & 0.50 \\
\hline $\mathbf{1 1 .}$ & TOTAL & 34.43 \\
\hline
\end{tabular}

Table 3. World's Top Ten Producers of Groundnut (Groudnut) [43].

It has been estimated that in the year 2000, approximately 34 million Mt of groundnuts were produced world wide of which 15 million Mt were produced in China, 6 million Mt in India, 2 
million Mt in Nigeria, 1.5 million Mt in United States of America and the rest mostly in other countries [45]. Groundnuts are important component of Nigerian diet and about 5 percent of the estimated $58.9 \mathrm{~g}$ of crude protein available per head per day is contributed by groundnut [45]. In most of the developing countries it provides high-quality cooking oil and is an important source of protein for both human and animal diet and also provides much needed foreign exchange by exporting the kernels and cake. Hence, the utilization of groundnut oil for biodiesel production without affecting the supply of the vegetable oil for consumption.

\section{Material and methodology}

The feedstock used in this work for the production of biodiesel is refined groundnut oil produced by Grand Cereals Mill Zawan, Plateau state, Nigeria. This product was purchased at a local super market in Minna Niger State, Nigeria. The entire chemicals used in this study are of analytical grade (98-99.5\%). They include Carbon tetra chloride (Analar, BDH), Wij's solution (Mixture of glacial acetate, iodine trichloride and carbon tetralchloride) (Hopkins and Williams, London), potasium hydroxide solution (Analar, BDH), potassium hydroxide pellet (Burgoyne \& co, India), petroleum ether (Analar, BDH), potassium iodide solution (M\&B, England), sodium thisosulphate (M\&B, England), hydrochloric acid (Analar, $\mathrm{BDH})$ and potassium iodide pellet (M\&B, England). The equipments used are $\mathrm{pH}$ meter, distillation apparatus, viscometer, thermostatic hot plate, sulphur in oil analyzer, magnetic stirrer, digital weighing balance, thermometer, petri dish, pippete, separating funnel, burete, oil test centrifuge, pycometer bottles, Abbe refractometer, flash point tester, oven and aneline point teseter.

Production of biodiesel from groundnut oil was carried out in accordance to the experimental procedure reported by Hill (2002) [45]. Methoxide was first prepared in a suitable container by dissolving sodium hydroxide in methanol. This typically consists of $50 \%$ methanol by volume of oil and 0.25 grams sodium hydroxide for lower limit and 0.50 grams sodium hydroxide for upper limit mixed together well so that the sodium hydroxide is completely dissolved in the methanol in the ratio of 1:4 for lower limit and 1:6 for upper limit respectively. Transesterification reactions were carried out in a reaction vessel $(250 \mathrm{ml}$ flask). The reactor was filled with $50 \mathrm{~g}$ refined groundnut oil sample and preheated to the selected reaction temperature $\left(40^{\circ} \mathrm{C}\right.$ and $\left.60^{\circ} \mathrm{C}\right)$; the methoxide solution was then added on top of the oil. The mixture was agitated vigorously for about 30 seconds and then placed on a magnetic stirrer for stirring to continue for the reaction time (45 and 90 minutes respectively). The transesterification was carried out on the hot plate to keep the reaction temperature constant, after reaction time was reached, the reaction mixture was then poured into a separating funnel and allowed to settle gravitationally for about 8-20hrs. After settling, a lighter colored biodiesel on top of a layer of darker glycerin was observed. The bottom layer (glycerol) was drained off and the top layer (methyl esters) was collected in a clean beaker.

Characterization of the feedstock (refined groundnut oil) is very important for proper understanding of its chemical composition, as well as physico-chemical properties to ease comparison with standard and possibly establish the level of purity of the material relative 
to using it for biodiesel production. Properties of the feedstock tested for are the specific gravity (or density), flash point, kinematic viscosity, acid value, iodine value, sulphur content, moisture content, free fatty acid and acid value. Determination of these properties was carried out using the experimental description reported by Onwuka (2005) [46]. Next to the prelimenary production of biodiesel from groudnut oil was the process optimization by investigating the effects of various parameters on the yield of biodiesel from groudnut oil.

Effects of operating parameters such as temperature, time of reaction, and catalyst concentration as well as oil-methanol mass (or mole) ratio were investigated. A $2^{4}$ factorial experimental design was used to carry out the study. A $2^{4}$ factorial experimental design was used to determine the optimum conditions for biodiesel production from groundnut oil, four variables were studied at both high and low levels. The expected response is biodiesel (methyl ester) yield. The low level of methanol: oil mass ratio was 6:1 and the high level was 4:1. The low level of catalyst concentration chosen was $0.5 \%$ and the high level was $1.0 \%$ $\mathrm{NaOH}$ catalyst by weight of groundnut oil. The low level of temperature was chosen as 40 ${ }^{\circ} \mathrm{C}$ and the high level was chosen at $60{ }^{\circ} \mathrm{C}$, which was determined by the boiling point of methanol. The reaction time chosen for the lower level was 45 minutes and 90 minutes for the higher level. Table 4 shows the experimental matrix for the $2^{4}$ factominrial designs (4factors, each run at two levels). The biodiesel produced was then analyzed to determine the specific gravity, flash point, cloud point, kinematic viscosity, pour point, centane number, acid value, bottom water and sediment, sulphur content, ash content and distillation characteristics. All experimental analysis were conducted in triplicate and the results reported are the average values with average deviation of \pm 0.0015

\begin{tabular}{|l|c|c|c|c|}
\hline Run & $\begin{array}{c}\text { Temperature } \\
\left({ }^{\circ} \mathrm{C}\right)\end{array}$ & $\begin{array}{c}\text { Methanol : oil ratio } \\
(\mathrm{wt} / \mathrm{wt})\end{array}$ & $\begin{array}{c}\text { Catalyst Conc. } \\
(\mathrm{wt} \%)\end{array}$ & $\begin{array}{c}\text { Reaction } \\
\text { time (min) }\end{array}$ \\
\hline 1 & 40 & $1: 4$ & 0.5 & 45 \\
\hline 2 & 60 & $1: 4$ & 0.5 & 45 \\
\hline 3 & 40 & $1: 6$ & 0.5 & 45 \\
\hline 4 & 60 & $1: 6$ & 0.5 & 45 \\
\hline 5 & 40 & $1: 4$ & 1.0 & 45 \\
\hline 6 & 60 & $1: 4$ & 1.0 & 45 \\
\hline 7 & 40 & $1: 6$ & 1.0 & 45 \\
\hline 8 & 60 & $1: 6$ & 1.0 & 45 \\
\hline 9 & 40 & $1: 4$ & 0.5 & 90 \\
\hline 10 & 60 & $1: 4$ & 0.5 & 90 \\
\hline 11 & 40 & $1: 6$ & 0.5 & 90 \\
\hline 12 & 60 & $1: 6$ & 0.5 & 90 \\
\hline 13 & 40 & $1: 4$ & 1.0 & 90 \\
\hline 14 & 60 & $1: 4$ & 1.0 & 90 \\
\hline 15 & 40 & $1: 6$ & 1.0 & 90 \\
\hline 16 & 60 & $1: 6$ & 1.0 & 90 \\
\hline
\end{tabular}

Table 4. $2^{4}$ Factorial design 


\section{Results and discussion of results}

Refined groundnut oil that was used as the feedstock for the production of biodiesel was characterized to determine the necessary properties that are very essential to the quality and quantity of the final product. Table 5 summarized the results obtained on the qualities of the refined groundnut. Presented in Table 6 is the results obtained on the influence of the operating parameters on the yield of biodiesel, while Table 7 represent the properties of the biodiesel produced from refined groundnut oil. Also presented is the statistical analysis of the results obtained to illustrate the effect of each of the operating parameters on the yield of the biodiesel from the refined groundnut oil.

Table 5 summarized the results of characterization carried out on the sample of refined groundnut oil used and the results were compared with standard and available literature. The main properties determined include saponification value, iodine value, acid value, free fatty acid, peroxide value, refractive index, kinematic viscosity, $\mathrm{pH}$, unsaponifiable matter and the moisture content, results obtained are hereby presented.

The saponification value of as reported by Al-Zahrani (2005) [48] is a measure of the tendency of oil to form soap during transesterification reaction (i.e. define as the number in milligram (mg) of $\mathrm{KOH}$ required to saponified $1 \mathrm{~g}$ of the sample fat).The saponification value obtained for sample of refined groundnut oil was 186.53, which is lower compared to 188195 recommended by AOCS standard(1998) [46], but higher than 148.67 reported for the variety used by Ibeto et al. (2011) [47].The high saponification values indicate the presence of high percentage of fatty acids which might lead to soap formation and hence low biodiesel yield [48]. Unsaponifiable matter are those substances frequently found dissolved in fatty acids and drying oils which cannot be saponified by caustic treatment, but which are soluble in normal fat solvents. The unsaponifiable value for the oil sample used oil was $0.29 \%$ which is very reasonable compared to $1 \%$ maximum recommended by AOCS standards as presented in Table 5. Iodine Value (IV) is a value of the amount of iodine, measured in grams, absorbed by 100 grams of given oil. The iodine value is expressed in grams of iodine for the amount of halogens linked with $100 \mathrm{~g}$ test sample, and is used as degree of unsaturated bond of fats and oils. Iodine values are used to classify oils as either drying oil (>130), semi-drying oil (115-130) and non-drying oil (<115) (Othmer, 2011) [49]. The oil used in the present study has iodine value of $94.16 \mathrm{gI}_{2} / 100 \mathrm{~g}$, although higher than $89.46 \mathrm{gI}_{2} / 100$ greported for the groundnut oil sample used by Ibeto et al. (2011) [47] but falls within the $84-100 \mathrm{gI}_{2} / 100 \mathrm{~g}$ range recommended by AOCS standard of 1998 . Based on this value, the present oil in use can be classified as non-drying oil. Also measured is the acid value (AV) of the oil which is an important indicator of vegetable oil quality. Vegetable oils with high acid value are classified as inedible while those with low acid value are classified as edible oils [48]. The obtained acid value for the present oil sample was $2.174 \mathrm{mgKOH} / \mathrm{g}$, a value that falls within $0.72-3.0 \mathrm{mgKOH} / \mathrm{g}$ reported in the AOCS standard (1998) [46] but lower when compare to $2.61 \mathrm{mgKOH} / \mathrm{g}$ obtained by Ibeto et al (2011) [47]. However, both reported values of the present study and that of Ibeto et al. (2011) [47] indicated the oil 
samples are edible type. Results as presented in Table 5 also indicate that the Free Fatty Acid (FFA) value of the refined groundnut oil sample was $0.05 \%$, and was found to fall within the AOCS standard having its FFA value as $<1 \%$ (AOCS, 1998). Literature also revealed that for groundnut oil to be fit for biodiesel production its free fatty acid content should be $<2 \%$, this is to enable efficient conversion of the oil into biodiesel (Anggraini and Wiederwertung, 1999) [50]. Ibeto et al (2011) obtained a free fatty acid value of $1.31 \mathrm{mgKOH} / \mathrm{g}$, translating to $0.065 \%$ which was a little bit higher than $0.05 \%$ reported in this study.

\begin{tabular}{|c|c|c|c|c|c|}
\hline $\mathrm{S} / \mathrm{No}$ & Properties & Unit & $\begin{array}{l}\text { Experimental } \\
\text { values }\end{array}$ & $\begin{array}{c}\text { AOCS } \\
\text { Standard value } \\
(1998)\end{array}$ & $\begin{array}{c}\text { Ibeto et } \\
\text { al., } \\
(2011)\end{array}$ \\
\hline 1. & Specific gravity (S.G) & - & 0.91 & $0.910-0.915$ & 0.93 \\
\hline 2. & $\begin{array}{l}\text { Kinematic Viscosity at } \\
25^{\circ} \mathrm{C}\end{array}$ & $\mathrm{mm}^{2} \mathrm{sec}^{-1}$ & 38.00 & - & 32.66 \\
\hline 3. & Saponification value (S.V) & $\mathrm{mgKOH} / \mathrm{g}$ & 186.53 & 188-195 & 148.67 \\
\hline 4. & Moisture content & $\%$ & 0.05 & - & 0.09 \\
\hline 5. & Iodine value (I.V) & $\mathrm{gI}_{2} / 100 \mathrm{~g}$ & 94.16 & $84-100$ & 89.46 \\
\hline 6. & Unsaponifiable matter & $\%$ & 0.29 & $1 \% \max$ & - \\
\hline 7. & $\mathrm{pH}$ & & 5.56 & - & - \\
\hline 8. & $\begin{array}{l}\text { Refractive index (R.I) at } \\
25^{\circ} \mathrm{C}\end{array}$ & - & 1.467 & $1.467-1.470$ & 1.463 \\
\hline 9. & Acid value (A.V) & $\mathrm{mgKOH} / \mathrm{g}$ & 2.174 & $0.72-3.0$ & 2.61 \\
\hline 10. & Free fatty acid (FFA) & $\%$ & 0.05 & $<1 \%$ & 1.31 \\
\hline 11. & Peroxide value & $\mathrm{mEq} / \mathrm{kg}$ & 0.059 & - & 22.25 \\
\hline
\end{tabular}

Table 5. Measured Physiochemical Properties of Refined groundnut oil.

Kinematic viscosity refers to the thickness of the oil and its value is meaningless unless accompanied by the temperature at which it is determined. The purpose of transesterified vegetable oils and animal fats into alkyl esters (biodiesel) is to reduce the kinematic viscosity because high viscosity tends to form larger droplets on injection which can cause poor combustion, increased exhaust smoke and emissions. Hence, kinematic viscosity is key factor in checking suitability of a feedstock for the production of biodiesel. Result obtained as presented in Table 5 shown that the kinematic viscosity of the refined groundnut utilized in this study for the production of biodiesel is $38 \mathrm{~mm}^{2} / \mathrm{sec}$ at $25^{\circ} \mathrm{C}$, which is much higher compared to $32.66 \mathrm{~mm}^{2} / \mathrm{sec}$ obtained by Ibeto et al (2011). While the specific gravity of the refined groundnut oil was found to be 0.91, which falls within the range of AOCS specification (0.910-0.915) and lower than 0.93 reported by Ibeto et al. (2011). The peroxide value obtained for the refined groundnut oil was $0.059 \mathrm{mEq} / \mathrm{kg}$ which was very low compared to $22.25 \mathrm{mEq} / \mathrm{kg}$ obtained by Ibeto et al (2011). The value obtained is considered reasonable, because literature suggest that the peroxide values of fresh oils should be less 
than 10 millequivalents $/ \mathrm{kg}$, peroxide values between 30 and 40 millequivalents $/ \mathrm{kg}$ will results into rancidity of the oil. The moisture content in the oil sample as shown in Table 5 was found to be $0.05 \%$ and much lower compared to $0.09 \%$ reported for the oil sample used by Ibeto et al (2011).The $0.05 \%$ value obtained agreed with the value recommended by ASTM (D 6571) and falls within the $<3 \%$ moisture content suggested for all raw materials to be used in the production of biodiesel (Freedman et al., 1984). It has been reported that moisture content greater than $<3 \%$ will decrease the efficiency of the transesterification reaction due to possibility deactivation of catalyst active sites and soap formation (Freedman et al., 1984). The result obtained on the refractive index of the oil sample at $25^{\circ} \mathrm{C}$ was 1.467 which was within the recommended AOCS standard index of 1.467-1.470 and also compared well with 1.463 reported by Ibeto et al. (2011). It can be inferred from the various analysis conducted on the refined groundnut oil sample that the oil sample compare favorably with the standard and literature value, hence the oil sample utilized in this study should produced biodiesel with high yield and quality.

The effect of reaction parameters on the yield of biodiesel produced from refined groundnut oil was investigated using a $2^{4}$ factorial design. Reaction parameters considered include mole ratio of methanol to refined groundnut oil, reaction temperature, catalyst concentration and reaction time. Each of these parameters was considered at two specified levels and the summary of results obtained was presented in Table 6. As shown in Table 6, the best biodiesel yield of $99 \%$ was obtained under the optimal conditions of 1:6 (oil to methanol) molar ratio, $0.5 \%$ catalyst concentration at $40^{\circ} \mathrm{C}$ and for a reaction time of 90 minutes. This value was better than $88 \%$ and $79 \%$ reported by Galadima et al.(2008) and Ibeto et al .(2011) respectively. The better ester production yield obtained could be attributed to different reaction parameters used in conducting the experiment, different alcohol and alkali catalyst and possible variation in the specie of groundnut oil used which is attested to the values obtained for the characterization of the oil (Table 5).

One of the most important parameters that affects biodiesel yield is the oil: alcohol ratio (in this case refined groundnut oil to methanol) mole ratio [51]. In order to evaluate its effect on biodiesel yield, transesterification was conducted at two different molar ratios of 1:4 and 1:6. Though, the stoichiometric ratio for transesterification requires one (1) mole of triglyceride and three (3) moles of alcohol to yield three moles of fatty acid alkyl esters and one mole of glycerol. However, transesterification is an equilibrium reaction in which a large excess of alcohol is required to drive the reaction to the product side. In this work, two levels of Groundnut Oil to $\mathrm{MeOH}$ molar ratio were used, 1:4 for the low level and 1:6 for the high level. The yields ranging from $94-99 \%$ were obtained at a molar ratio of $1: 6$. It can be seen from Figure 2 that the biodiesel yield increased for both $0.5 \mathrm{wt} \%$ and $1.0 \mathrm{wt} \%$ catalyst concentration as the molar ratio was increased from 1:4 to 1:6 i.e. from 96 to $99 \%$ for $0.5 \mathrm{wt} \%$ and from 80 to $92 \%$ for $1.0 \mathrm{wt} \%$ catalyst weight respectively. While temperature and time were constant and this achieved experimental result is in agreement with Freedman et al (1984) [52]. Since transesterification is an equilibrium process, lower oil to methanol molar ratio may result in an incomplete transesterification and thus increasing the molar ratio which will shift the reaction to the ester formation direction. However when the molar ratio 


\begin{tabular}{|l|c|c|c|c|c|c|c|}
\hline Run & Temperature & $\begin{array}{c}\text { Oil: } \\
\text { Methanol } \\
\text { mole } \\
\text { ratio }\end{array}$ & $\begin{array}{c}\text { Catalyst } \\
\text { weight } \\
(\text { wt \%) }\end{array}$ & $\begin{array}{c}\text { Reaction } \\
\text { time }\end{array}$ & $\begin{array}{c}\text { Production } \\
\text { yield (wt \%) }\end{array}$ & $\begin{array}{c}\text { Methyl ester } \\
\text { concentration } \\
(\text { wt \%) }\end{array}$ & $\begin{array}{c}\text { Methyl } \\
\text { ester } \\
\text { yield } \\
\text { wt \%) }\end{array}$ \\
\hline 1 & 40 & $1: 4$ & 0.50 & 45 & 96 & 97.92 & 94 \\
\hline 2 & 60 & $1: 4$ & 0.50 & 45 & 90 & 80.00 & 72 \\
\hline 3 & 40 & $1: 6$ & 0.50 & 45 & 96 & 97.92 & 94 \\
\hline 4 & 60 & $1: 6$ & 0.50 & 45 & 98 & 97.96 & 96 \\
\hline 5 & 40 & $1: 4$ & 1.00 & 45 & 94 & 97.87 & 92 \\
\hline 6 & 60 & $1: 4$ & 1.00 & 45 & 76 & 92.11 & 70 \\
\hline 7 & 40 & $1: 6$ & 1.00 & 45 & 96 & 93.75 & 90 \\
\hline 8 & 60 & $1: 6$ & 1.00 & 45 & 96 & 95.83 & 92 \\
\hline 9 & 40 & $1: 4$ & 0.50 & 90 & 100 & 96.00 & 96 \\
\hline 10 & 60 & $1: 4$ & 0.50 & 90 & 98 & 97.96 & 96 \\
\hline 11 & 40 & $1: 6$ & 0.50 & 90 & 101 & 98.02 & 99 \\
\hline 12 & 60 & $1: 6$ & 0.50 & 90 & 98 & 97.96 & 96 \\
\hline 13 & 40 & $1: 4$ & 1.00 & 90 & 82 & 97.56 & 80 \\
\hline 14 & 60 & $1: 4$ & 1.00 & 90 & 80 & 95.00 & 76 \\
\hline 15 & 40 & $1: 6$ & 1.00 & 90 & 94 & 97.87 & 92 \\
\hline 16 & 60 & $1: 6$ & 1.00 & 90 & 92 & 97.83 & 90 \\
\hline
\end{tabular}

Table 6. Biodiesel Yield at Different Conditions

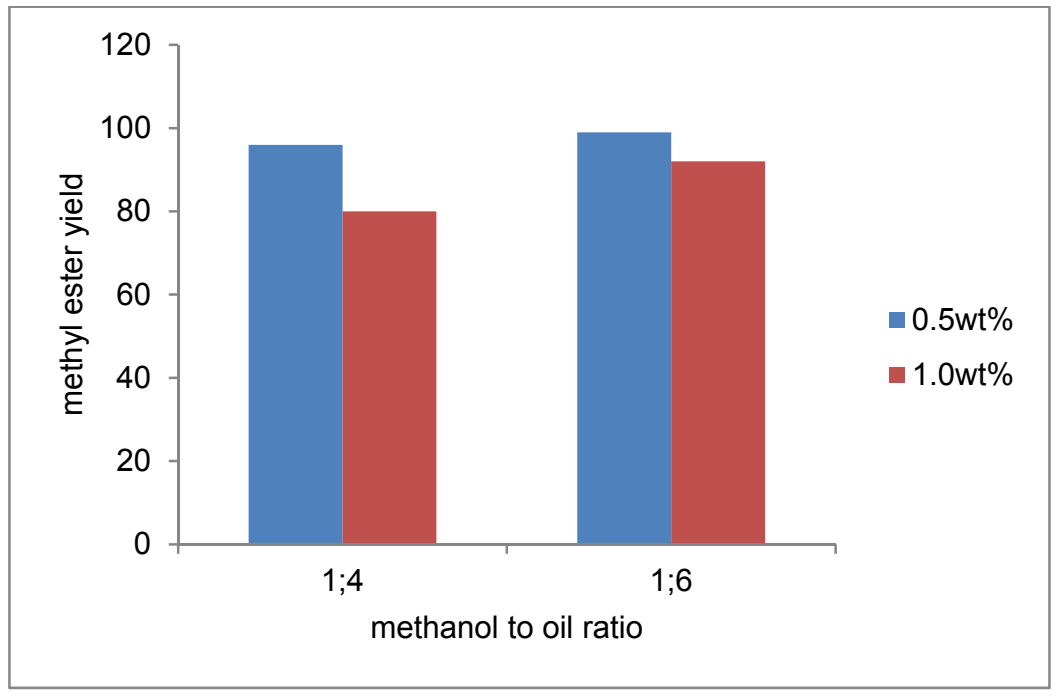

Figure 2. Effect of methanol to oil ratio on methyl ester yield at $40^{\circ} \mathrm{C}$ and 90 minutes reaction time.

is set too high, the excessive alcohol may favor conversion of triglycerides to diglycerides and then monoglycerides and a slight recombination of esters and glycerol to 
monoglycerides because their concentrations keep increasing during the course of the reaction. The detailed analysis of the results obtained on the effects of various parameters on the yield of biodiesel from groudnut oil are presented below.

The rate of reaction and biodiesel yield can be affected by reaction temperature, Anitha and Dawn, (2010) in their work varied the temperature between $40-65^{\circ} \mathrm{C}$ and concluded that the primary advantage of a high temperature is shorter reaction time. Transesterification can occur at different temperatures depending on the oil used. Several researchers found that the temperature increase influences the reaction in a positive manner (Ma and Hanna, 1990; Freedman et al., 1984; Canakci and Van Gerpen, 1999). Though, it has been reported that the best temperature for the reaction is $60^{\circ} \mathrm{C}$ but depending on the type of catalyst, different temperatures will give different degrees of conversion. In this work, the two levels of temperature used were $40^{\circ} \mathrm{C}$ for the low level and $60^{\circ} \mathrm{C}$ for the high level. The best yields were obtained at the low temperature of $40^{\circ} \mathrm{C}$ as presented in Figure 3. This pattern of results can be attribute to the fact at a high temperature of $60^{\circ} \mathrm{C}$ most of the alcohol in the biodiesel would evaporate during transesterification reaction leading to a lower yield Anitha and Dawn (2010), also confirmed this. The figure also confirmed that as the temperature increase from $40^{\circ} \mathrm{C}$ to $60^{\circ} \mathrm{C}$ the methyl ester yield decreased from 94 to $92 \%$ for $0.5 \mathrm{wt} \%$ catalyst weight and from 92 to $70 \%$ for $1.0 \mathrm{wt} \%$ catalyst weight respectively.

Analysis of result obtained as presented in Table 5 shows that increase in time does not implies increase in yield as suggested by Yusuf and Sirajo (2009). For instance, at $40^{\circ} \mathrm{C}$ using 1:4 mole ratios with $1 \mathrm{wt} \%$ catalyst for $45 \mathrm{~min}$ gave a yield of $92 \%$ while the yield decreased to $80 \%$ at the same condition but with $90 \mathrm{~min}$ reaction time. In this study, two levels of reaction time were used i.e. 45 minutes for the low level and 90 minutes for the high level. The optimum yield (99\%) was achieved at 90 minutes and this observation is in agreement with Freedman's work and Ahmad et al., (2009). Figure 4 which also depict the effect of time on the methyl ester yield indicate that the maximum methyl ester yield at 45 minutes was

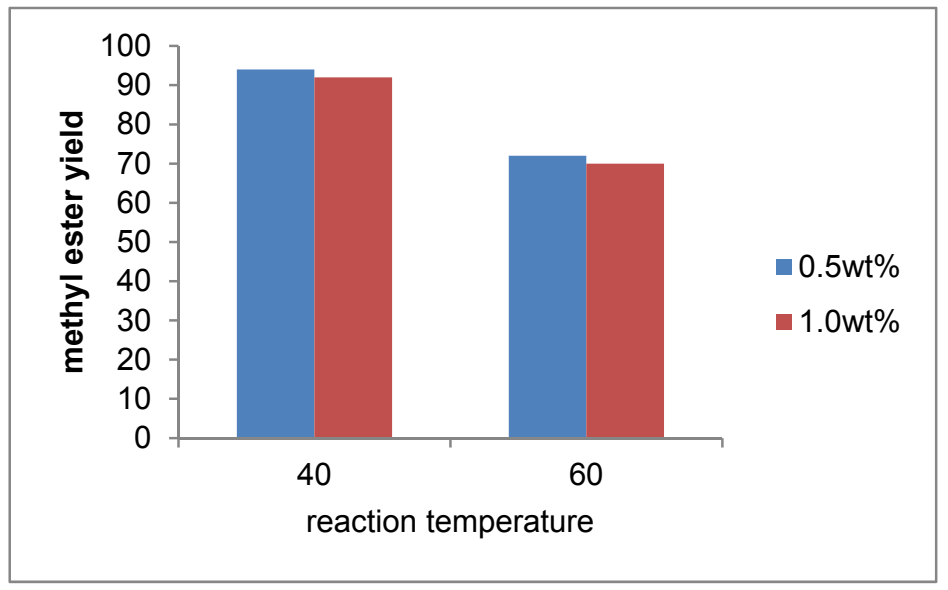

Figure 3. Effect of reaction temperature on methyl ester yield at $40^{\circ} \mathrm{C}$ at 45 minutes reaction time. 


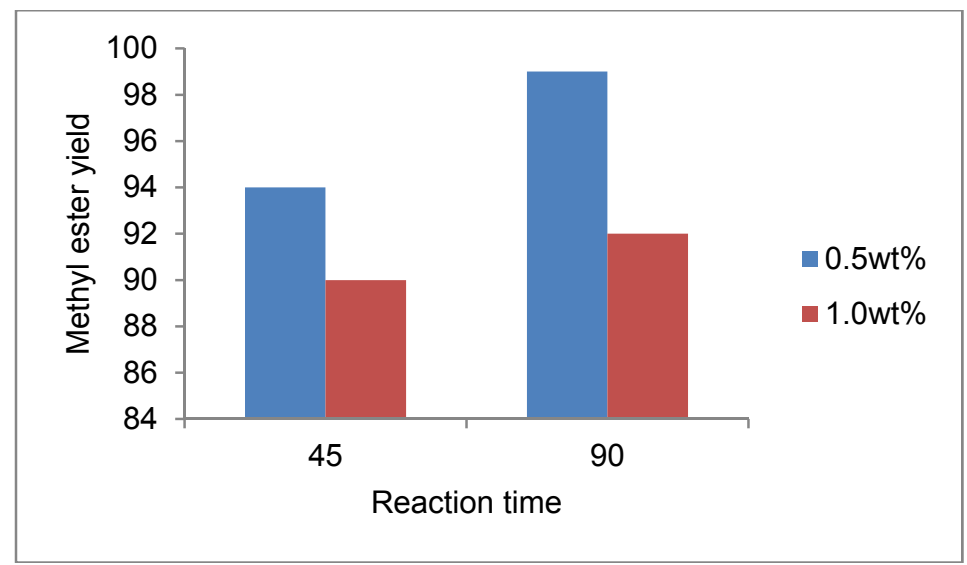

Figure 4. Effect of reaction time on methyl Ester Yield at $40^{\circ} \mathrm{C}$ using 1:6 methanols to oil ratio.

$96 \%$ which is less than the value obtained at 90 minutes (99\%) at same reaction conditions. This indicates that there is increase in biodiesel yield as reaction time increases although this could be as a result of varying other variables too.

Also investigated is the effect of catalyst on the yield of the biodiesel from grudnut oil. It has been reported that as the catalyst concentration increases, the conversion of triglyceride and the yield of biodiesel also increase. This phenomenon was attributed to an increase in the availability and number of catalytically active sites (Anitha and Dawn, 2010). This is because an insufficient amount of catalysts will result in an incomplete conversion of the triglycerides into the fatty acid esters (Anitha and Dawn, 2010). Two levels of catalyst concentration $(\mathrm{NaOH})$ were used in this work, $0.5 \mathrm{wt} \%$ for the lower and $1.0 \mathrm{wt} \%$ for the higher level. From the obtained experimental result shown in Table 6 and Figure 5, it was observed that the best yield which was $99 \%$ was obtained at $0.5 \mathrm{wt} \% \mathrm{NaOH}$, but at $40^{\circ} \mathrm{C}, 1: 6$ and a reaction time of 90 minutes. Although the smaller the catalyst concentration, the lower the yield due to insufficient amount of catalyst to catalyze the reaction to a completion stage but this result was achieved due to the excess of alcohol used in this condition. It can be seen from Figure 5 also that the methyl ester yield is higher at catalyst concentration of $0.5 \mathrm{wt} \%$ than at $1.0 \mathrm{wt} \%$. Also, it was observed that at conditions other than the optimal conditions of 1:6 molar ratio, $60^{\circ} \mathrm{C}$ and 90 minutes reaction time, $1.0 \mathrm{wt} \%$ catalyst weight gave a lower yield in most run than the $0.5 \mathrm{wt} \%$ for same conditions. Most researchers said that an increase in catalyst concentration increases the methyl ester yield (Anitha and Dawn, 2010; Yusuf and Sirajo, 2009) but from this research, higher catalyst concentration gave lower yield, as shown in Figure 5.

Biodiesel produced from refined groundnut oil using alkali catalyzed transesterification process with sodium hydroxide $(\mathrm{NaOH})$ as catalyst and methanol as alcohol was characterized to determine its suitability as alternative to petrol diesel. Results obtained on the various analysis conducted are presented in Table 7. 


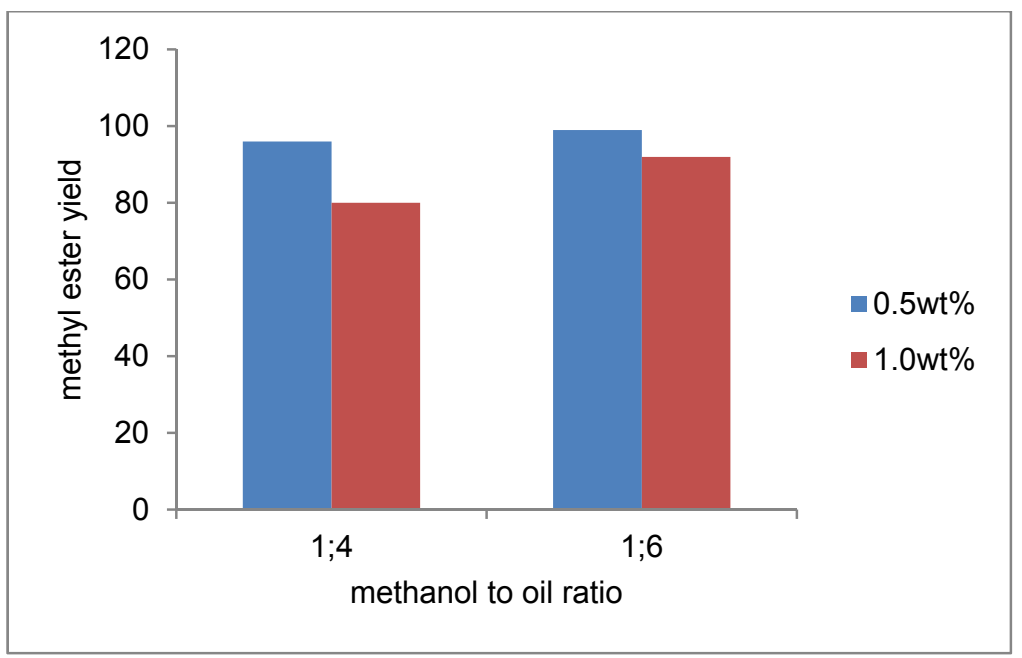

Figure 5. Effect of Catalyst Concentration on Ethyl Ester Yield.

Results as presented in Table 7 indicate that the kinematic viscosity of the biodiesel produced was determined as $5.86 \mathrm{~mm}^{2} / \mathrm{s}$, a value that falls within the range of $1.9-6.0 \mathrm{~mm}^{2} / \mathrm{s}$ recommended by ASTM (DS 6751) and a little higher than $5.16 \mathrm{~mm}^{2} / \mathrm{s}$ reported by Ibeto et al. (2011). However, the value obtained shows that the transesterification reaction has successfully reduced the viscosity of oil from $38 \mathrm{~mm}^{2} / \mathrm{s}$ to $5.86 \mathrm{~mm}^{2} / \mathrm{s}$ and as such increases its tendency to flow. Since kinematic viscosity described the resistance of a fluid to flow under gravity and it is important in determining optimum handling, storage, and operational conditions. High viscosity can cause fuel flow problems and lead to stall out or fuel pump failure [54]. Also presented in Table 7 is the results obtained for the bottom sediment and water content of the biofuel produced. Presence of water and sediment in biodiesel beyond standard limit will results in poor ignition, filter clogging, and fuel pump problems, sediment in storage tanks can obstruct the flow of fuel from the tank to a combustor and presence of water in middle distillate fuels can cause corrosion and growth of microorganisms. According to ASTM standard, a maximum water content of $0.05 \%$ vol fuels is acceptable, while the biodiesel produced contain trace quantity of water and sediment. This is similar to the results reported by Ibeto et al. (2011) and better than $0.02 \%$ water and sediment reported by Galadima et al. (2008) [53]. This result gave an indication that the biodiesel is clean and properly dried. Sulphur content of the biodiesel produced was measured and the result obtained is as shown in Table 7. Pure biodiesel (B100) is expected to contain very low quantities of sulfur in order to retain its traditional name of sulphur-free fuel. The sulphur content of the biodiesel produced was found to be $0.025 \mathrm{wt} \%$ (Table 7) and this is low when compared to ASTM maximum limit of $0.050 \mathrm{wt} \%$. It can be inferred that the fuel produced is "Sulphur free". Also presented in Table 7 is the distillation characteristic of the produced biodiesel, though for a pure substance the boiling point is a single temperature value. However, when a mixture of hydrocarbons exists in diesel fuel there is a range of boiling points for the different constituent chemical specie, the boiling point of the biodiesel 


\begin{tabular}{|c|c|c|c|c|c|c|}
\hline Properties & Units & $\begin{array}{c}\text { Experimenta } \\
\text { l values }\end{array}$ & $\begin{array}{c}\text { ASTM } \\
\text { standard } \\
\text { biodiesel } \\
\text { (ASTM D 6751) }\end{array}$ & $\begin{array}{c}\text { ASTM } \\
\text { standard } \\
\text { Petrol-diesel } \\
\text { (ASTM D 975) }\end{array}$ & $\begin{array}{l}\text { Ibeto et al., } \\
\text { (2011) }\end{array}$ & $\begin{array}{c}\text { Galadima et } \\
\text { al., (2008) }\end{array}$ \\
\hline $\begin{array}{l}\text { Specific } \\
\text { gravity }\end{array}$ & - & 0.88 & - & $0.95 \max$ & 0.88 & 0.84 \\
\hline $\begin{array}{c}\text { Kinematic } \\
\text { Viscosity at } \\
40^{\circ} \mathrm{C}\end{array}$ & $\mathrm{mm}^{2} / \mathrm{s}$ & 5.86 & $1.9-6.0$ & $1.9-4.1$ & 5.16 & - \\
\hline Flash point & ${ }^{0} \mathrm{C}$ & 170 & 130min & $60-80$ & $\begin{array}{c}202^{\circ} \mathrm{C}\left(395.6^{\circ} \mathrm{F}\right. \\
)\end{array}$ & - \\
\hline Cloud point & ${ }^{0} \mathrm{~F}$ & 57 & - & -15 to 5 & - & - \\
\hline $\begin{array}{c}\text { Sulphur } \\
\text { content (by X- } \\
\text { Ray) } \\
\end{array}$ & $\%$ mass & 0.025 & $0.05 \max$ & $0.05 \max$ & - & - \\
\hline $\begin{array}{c}\text { Distillation } \\
\text { I.B.P }\end{array}$ & ${ }^{\circ} \mathrm{C}$ & 350 & - & - & - & - \\
\hline $10 \%$ & ${ }^{0} \mathrm{C}$ & 355 & - & $70 \max$ & - & - \\
\hline $50 \%$ & ${ }^{0} \mathrm{C}$ & 365 & - & $125 \max$ & - & - \\
\hline $80 \%$ & ${ }^{0} \mathrm{C}$ & $>400$ & - & $180 \max$ & - & - \\
\hline E.B.P & ${ }^{0} \mathrm{C}$ & - & $360 \max$ & & & \\
\hline $\begin{array}{c}\text { Total } \\
\text { recovery }\end{array}$ & - & $97 \%$ & - & - & - & - \\
\hline Cetane index & _- & 49.56 & $47 \mathrm{~min}$ & $40-55$ & - & - \\
\hline Ash content & $\%$ mass & 0.016 & 0.02 & - & - & \\
\hline $\begin{array}{c}\text { Free } \\
\text { glycerine }\end{array}$ & $\%$ mass & 0.018 & $0.02 \max$ & 0.02 & - & - \\
\hline $\begin{array}{c}\text { Total } \\
\text { Glycerine }\end{array}$ & $\%$ mass & 0.240 & $0.24 \max$ & 0.24 & - & - \\
\hline Acid value & $\begin{array}{c}\mathrm{mg} \\
\mathrm{KOH} / \mathrm{g}\end{array}$ & 0.210 & $0.5 \max$ & - & 4.96 & 0.45 \\
\hline $\begin{array}{l}\text { Water by } \\
\text { distillation }\end{array}$ & $\%$ vol & Trace & $0.05 \max$ & $0.5 \max$ & Trace & - \\
\hline $\begin{array}{c}\text { Basic water } \\
\text { and Sediment }\end{array}$ & $\%$ vol & Trace & $0.05 \max$ & $0.5 \max$ & Trace & 0.02 \\
\hline
\end{tabular}

Table 7. Measured Properties of biodiesel produced

produced was taken at its initial boiling point (IBP), at $10 \%, 50 \%$, and $80 \%$ and at its end boiling point, the values obtained for each of them were $350^{\circ} \mathrm{C}, 355^{\circ} \mathrm{C}, 365^{\circ} \mathrm{C}$ and $>400^{\circ} \mathrm{C}$ respectively these values were found to be much higher than the ASTM D 6751 due to the fact that a vacuum distillation apparatus was used. An acid value of the produced biodiesel was also measured and the result is presented in Table 7. The acid number correlates to the fuel's long-term stability and corrosiveness, the smaller the acid value, the higher the quality of the fuel. The acid value of the biodiesel produced was found to be $0.210 \mathrm{mgKOH} / \mathrm{g}$, a 
value lower compared to the maximum recommended standard value of $0.5 \mathrm{mgKOH} / \mathrm{g}$ (ASTM D 6751) and better than 4.96 and $0.45 \mathrm{mgKOH} / \mathrm{g}$ reported by Ibeto et al. (2011) and Galadima et al. (2008) respectively. The Cetane number relates to the readiness of the fuel to self-ignite when exposed to the high temperatures and pressure in the diesel engine combustion chamber. The cetane number affects a number of engine performance parameters such as combustion, stability, drivability, white smoke, noise and emission of $\mathrm{CO}$. The number is also indicative of the relative fuel stability [55]. The cetane number of the biodiesel produced was calculated as 49.5, a value above the ASTM acceptable minimum of 47(as expected) which indicates ignition delay and better ignition properties [55].

Also measure and presented in the table of result is the flash point of the produced biodiesel, which is described as a tendency of a sample of fuel to form a flammable mixture with air. The flash point of the biodiesel produced was found to be $170^{\circ} \mathrm{C}$ which is greater than the minimum acceptable value of $130^{\circ} \mathrm{C}$ specified by ASTM D 6751 (Table 7). Cloud point is a fuel property that is particularly important for the low temperature operability of diesel fuel. Initially, cooling temperatures cause the formation of solid wax crystal nuclei that are submicron in scale and invisible to the human eye. The temperature at which crystal agglomeration is extensive enough to prevent free pouring of fluid is called its pour point [56]. In this work, the cloud point of the biodiesel was determined as $20^{\circ} \mathrm{F}$ and is in accordance with the work of Dunn et al., (1996) [57]. These features have implications on the use of biodiesel in cold weather applications. Free and total glycerin values are indicators of incomplete esterification reactions and predictors of excessive carbon deposits in the engine it shows the mono, di and triglycerides molecule in the biodiesel. The total and free glycerin determined for the biodiesel produced was $0.018 \mathrm{wt} \%$ and $0.24 \mathrm{wt} \%$ respectively, both values were seen to be within the acceptable standard of ASTM D 6751 (Table 7) and also agreed with finding of Ibeto et al.(2011) except for slight difference in free glycerine which they obtained $0.02 \mathrm{wt} \%$.

The regression model of experimental data with respect to methyl ester conversion can be determined by least squares method. A statistical analysis was carried out on the experimental results obtained using analysis of variance (ANOVA). Effects of the four (4) factors and their interaction effect were estimated. The results of test of statistical significance in Table 8 shows that the four reaction parameters: molar ratio, temperature, time and catalyst concentration had different degrees of effects on the ethyl ester yield percentage with contributions of $11.5022 \%, 23.2275 \%, 14.5916 \%$ and $2.81534 \%$ respectively .

Table 8 shows that temperature had the highest effect of 8.4375 and the highest percentage contribution on methyl ester yield than other parameters having 23.23\% contribution. Molar ratio showed the least effect of -5.9375 and a \%contribution of 14.5916 on methyl ester yield. Catalyst concentration had an effect of -6.6875 with a percentage contribution of $14.5916 \%$. The reaction time had an effect of 2.9375 but the least contribution on methyl ester yield with $2.81534 \%$. It was also observed that the interaction effect between the factors were very significant. For instance, interactions between two factors such as temperature - molar ratio $\left(A^{*} B\right)$ had the highest effect of 6.0625 with the highest percentage contribution $(11.9916 \%)$ 


\begin{tabular}{|l|l|l|l|}
\hline Term & Effect & SumSqr & \% Contribtion \\
\hline A-Molar Ratio & -5.9375 & 282.031 & 11.5022 \\
\hline B-Temperature & 8.4375 & 569.531 & 23.2275 \\
\hline C-Catalyst Weight & -6.6875 & 357.781 & 14.5916 \\
\hline D-Reaction Time & 2.9375 & 69.0313 & 2.81534 \\
\hline AB & 6.0625 & 294.031 & 11.9916 \\
\hline AC & 0.1875 & 0.28125 & 0.0114704 \\
\hline AD & 4.5625 & 166.531 & 6.79174 \\
\hline BC & 2.3125 & 42.7813 & 1.74477 \\
\hline BD & -2.0625 & 34.0313 & 1.38792 \\
\hline CD & -5.1875 & 215.281 & 8.77993 \\
\hline ABC & 0.6875 & 3.78125 & 0.154213 \\
\hline ABD & -5.9375 & 282.031 & 11.5022 \\
\hline ACD & -0.8125 & 5.28125 & 0.215388 \\
\hline BCD & 3.3125 & 87.7813 & 3.58003 \\
\hline ABCD & 1.1875 & 11.2813 & 0.460089 \\
\hline
\end{tabular}

Table 8. Effects of reaction parameters on methyl ester yield.

while temperature- reaction time $\left(B^{*} D\right)$ had the least effect of -2.0625 with the lowest percentage contribution of $1.388 \%$. For interactions between three factors for instance, temperature-catalyst concentration-reaction time $\left(B^{*} C^{*} D\right)$ had the highest effect of 3.3125 with a percentage contribution of $3.58003 \%$, while molar ratio-catalyst concentration-reaction time $\left(A^{*} C^{*} D\right)$ had the lowest effect of -0.8125 with a percentage contribution of $0.2154 \%$. In concise, the molar ratio and catalyst weight were seen to have negative effect but temperature and reaction time were seen to have positive effects, while all interactions also had positive effects with the exception of $\left(B^{*} D\right),\left(C^{*} D\right),\left(A^{*} B^{*} D\right)$ and $\left(A^{*} C^{*} D\right)$ which had negative effects. However, the negativity of interactions is probably due to side reactions such as soaps formation (Vicente et al., 1998). Table 10 present the variance analysis of the results.

The variance analysis of the results indicates that the Model F-value is 84.69 which implies that the model is significant as seen on Table6. this table shows the analysis of variance in which both the main effects(temperature, molar ratio of methanol-to-oil, rection time and catalyst weight), second order effect $(A B, A D, B C, B D, C D)$, third order effect $(A B D, B C D, A B C, A C D)$ and the fourth order effect(ABCD) are significant in the regression model but have no interaction effect. This implies that the values of "Prob > F" less than 0.0500 indicate model terms are significant. In this case $\mathrm{A}, \mathrm{B}, \mathrm{C}, \mathrm{D}, \mathrm{AB}, \mathrm{AD}, \mathrm{BC}, \mathrm{BD}, \mathrm{CD}, \mathrm{ABD}, \mathrm{BCD}, \mathrm{ABCD}$ are significant model terms. Values greater than 0.1000 indicate the model terms are not significant. Stastitical analysis of the results also indicates that S.D. $=1.38$; Mean $=89.47 ;$ C.V. $\%$ $=1.54 ; \mathrm{R}^{2}=0.9876 ; \mathrm{R}^{2}{ }_{A D J}=0.9759 ; \mathrm{R}^{2}$ PRED = 0.9502; PRESS = 122.00; Adequate Precision = 28.168.

The "Predicted R-Squared" of 0.9502 is in reasonable agreement with the "Adjusted RSquared" of 0.9759. "Adequate Precision" measures the signal to noise ratio. A ratio greater than 4 is desirable which shows that the ratio obtained 28.168 is adequate. 
The analysis of variance showed that A,B,C,Dwere significant factors. The mathematical equation models for predicting average methyl ester yield are the final equation in terms of coded factors (Equation 1) and final equation in terms of actual factors (Equation 2)

$$
\begin{gathered}
\mathrm{Y}=89.47-2.97 \mathrm{~A}+4.22 \mathrm{~B}-3.34 \mathrm{C}+1.47 \mathrm{D}+3.03 \mathrm{~A} * \mathrm{~B}+0.094 \mathrm{~A} * \mathrm{C}+2.28 \mathrm{~A} * \mathrm{D}+1.16 \mathrm{~B} * \mathrm{C} \\
-1.03 \mathrm{~B} * \mathrm{D}-2.59 \mathrm{C}{ }^{*} \mathrm{D}+0.34 \mathrm{~A} * \mathrm{~B} * \mathrm{C}-2.97 \mathrm{~A} * \mathrm{~B}{ }^{*} \mathrm{D} \\
-0.41 \mathrm{~A}{ }^{*} \mathrm{C}+{ }^{*} \mathrm{D} 1.66 \mathrm{~B} * \mathrm{C} * \mathrm{D}+0.59 \mathrm{~A} * \mathrm{~B}{ }^{*} \mathrm{C}{ }^{*} \mathrm{D} \\
\mathrm{Y}=453-95.00000 \mathrm{~A}-6.25000 \mathrm{~B}-76.00000 \mathrm{C}-4.31111 \mathrm{D}+1.62500 \mathrm{AB}+34.00000 \mathrm{AC} \\
+1.21111 \mathrm{AD}+1.35000 \mathrm{BC}+0.078889 \mathrm{BD}+1.06667 \mathrm{CD}-0.57500 \mathrm{ABC}-0.021111 \mathrm{ABD} \\
-0.60000 \mathrm{ACD}-0.023333 \mathrm{BCD}+0.010556 \mathrm{ABCD}
\end{gathered}
$$

From Equations 1 and 2, all coefficients in the first and third order term have a minus sign which indicates that the \%methyl ester conversion increases with these factors not conforming to the experimental result, while coefficients in the second and fourth order term have plus signs which indicates that the \%methyl ester conversion increases with these factors conforming to the experimental result and also indiccates that there are also optimums within the experimental condition range.

\section{Conclusion}

Biodiesel was successfully produced from refined groundnut oil via alkali catalyzed transesterification using methanol, in the presence of $\mathrm{NaOH}$. The produced biodiesel was characterized and from the results obtained, the methyl ester produced can be effectively used in a diesel engine since it meets the requirements of ASTM D 6751. Refined groundnut oil has also been proved to be a good feedstock for biodiesel as an optimum yield of $99 \%$ was obtained, and the obtained fuel properties such as kinematic viscosity $\left(5.86 \mathrm{~mm}^{2} / \mathrm{s}\right)$, flash point $\left(170^{\circ} \mathrm{F}\right)$, cetane number $(49.56)$, total sulphur content $(0.025 \mathrm{wt} \%)$, e.t.c. after detailed characterization of the produced methyl esters of the oil which were within the standard ascribed by ASTM. Reaction temperature, reaction time, catalyst concentration and molar ratio of methanol to groundnut oil are the main variables affecting the methyl ester yield. These variables were optimized using a $2^{4}$ factorial design while the agitation speed was kept constant at 200rpm and the optimum methyl ester yield $(99 \%)$ was obtained at optimum reaction parameters of $40^{\circ} \mathrm{C}$ reaction temperature, 90 minutes reaction time, $0.5 \mathrm{wt} \%$ catalyst concentration and methanol to oil molar ratio of $6: 1$.The regression models by least square method used to predict \% methyl ester conversion from groundnut oil shows that the main effect, first order effect, second order effect, third order and fourth order effect are significant with no interaction effect, the coefficient of determination $\mathrm{R}^{2}$ is 0.99. From the analysis of variance, it can be concluded that temperature had the highest effect and percentage contribution of 8.4375 and $23.2275 \%$ respectively to methyl ester yield from groundnut oil while molar ratio had the lowest effect $(-5.9375)$ and a percentage contribution of $11.50 \%$. It can also be concluded that from all the interaction effect of the four (4) reaction variables, $A, B, C, D, A B, A D, B C, B D, C D, A B D, B C D, A B C D$ were significant model terms. A simple first degree polynomial regression model that can predict the methyl ester yield from groundnut oil has been developed and represented as: 


$$
\begin{gathered}
\mathrm{Y}==453-95.00000 \mathrm{~A}-6.25000 \mathrm{~B}-76.00000 \mathrm{C}-4.31111 \mathrm{D}+1.62500 \mathrm{AB}+34.00000 \mathrm{AC} \\
+1.21111 \mathrm{AD}+1.35000 \mathrm{BC}+0.078889 \mathrm{BD}+1.06667 \mathrm{CD}-0.57500 \mathrm{ABC}-0.021111 \mathrm{ABD} \\
-0.60000 \mathrm{ACD}-0.023333 \mathrm{BCD}+0.010556 \mathrm{ABCD} .
\end{gathered}
$$

Based on the results of the various analysis conducted, it can be infered that, groundnut oil is a good feedstock for methyl ester production especially in Nigeria where it is cheap and readily available.

\section{Author details}

Jimoh A., Odigure J.O. and Odili U.C.

Department of Chemical Engineering, School of Engineering and Engineering Technology,

Federal University of Technology, PMB 65 Minna, Niger State, Nigeria

Abdulkareem A.S.*

Department of Chemical Engineering, School of Engineering and Engineering Technology, Federal University of Technology, PMB 65 Minna, Niger State, Nigeria

Department of Civil and Chemical Engineering, College of Science, Engineering and Technology,

University of South Africa, Private Bag X6, Florida 1710, Johannesburg, South Africa

Afolabi A.S.

Department of Civil and Chemical Engineering, College of Science, Engineering and Technology, University of South Africa, Private Bag X6, Florida 1710, Johannesburg. South Africa

\section{Acknowledgment}

Step B project, Federal University of Technology, Minna Nigeria is appreciated for their support. National Research Foundation (NRF), South Africa and Faculty of Science, Engineering and Technology, University of South Africa are also appreciated for their support.

\section{References}

[1] Abdulkareem, A.S.; Odigure, J.O. \& Kuranga. M.B. (2010). Production and Characterization of Bio-Fuel from Coconut oil. Energy Source Part A. J. 32 106-114.

[2] Sanchez, O.J. and Cardona, C.A. (2008). Trends in Biotechnical Production of Ethanol Fuel from Different Feedstocks, Bioresour. Technol., 37(2): pp. 133-140

[3] Balat, M. and Balat, H. (2009). Recent Trends in Global Production and Utilization of Bioethanol Fuel, Applied Energy Journal, 86: pp. 2273-2282.

[4] U.S. Department of Energy: Office of Fossil Energy. Retrieved from http://www.energy.gov/energysources/fossilfuels.htm/ on April 22, 2011.

[5] Alamu, O.J. (2007). Effect of Ethanol-Palm Kernel Oil Ratio on Alkali-Catalyzed Biodiesel Yield, Pacific Journal of Science and Technology, 8(2), pp 212-219.

\footnotetext{
${ }^{*}$ Corresponding Author
} 
[6] Munack, A., Krahl, J., Baum, K., Hackbarth, U., Jeberien, H.E., Schutt, C., Schroder, O., Walter, N., Bunger, J., Muller, M.M. and Weigel, A. (2001). Gaseous Compounds, Ozone Precursors, Particle Number and Particle Size Distributions, and Mutagenic Effects Due to Biodiesel, Trans. ASAE 44(3): pp. 179-191.

[7] Knothe, G. (2002). Analyzing Biodiesel: Standards and other Methods, Journal of the American Oil Chemist's Society, 83(10): pp. 823-833.

[8] Graboski, M.S., McCormick, R.L. (1998). Combustion of fat and vegetable oil derived fuels in diesel engines. Progress in Energy Combustion Science. J. 24, 125-164.

[9] Berchamns H.J and Hirata S (2008). Biodiesel Production from Crude Jatropha Curcas L Seed Oil with a high content of free fatty acids. Bioresources Technology. J. 99 1716-1721.

[10] Adeniyi, O.D.; Kovo, A.S.; Abdulkareem. A.S \& Chukwudozie. C. (2007): Ethanol Fuel Production from Cassava as a Substitute for Gasoline. Dispersion and Technology.J. 28 501-504.

[11] Carraretto, C.; Macor, A. \& Mirandola, A. (2004). Biodiesel as alternative fuel: Experimental analysis and energetic evaluation. Energy. J. 2195-2211.

[12] Gerpen, V.J. (2005). Biodiesel Processing and Production. Fuel Processing Technology. J. 86(10) 1097-1107.

[13] Helwani, Z.; Othman, M. R,; Aziz, N.; Fernando, W. J. N.\& Kim. J.(2009). Technologies for production of biodiesel focusing on green catalytic techniques: A review. Fuel Processing Technology.J. 90 1502-1514.

[14] Aghan D. (2005). Biodiesel production from vegetable oils via catalytic and non catalytic supercritical methanol tranestarification methods. rogress in energy and combustion. J. 31 406-487.

[15] Abdulkareem A.S., Uthman H., Afolabi A.S and Awonebe O.L (2011). Extraction and Optimization of Oil from Moringa Oleifera Seed as an Alternative Feedstock for the production of Biodeisel. Majid N, Mostafa K, editors. Sustainable Growth and Application in Renewable Energy Sources. InTech. Pp243-268.

[16] Abigor, R.D., Uadia, P.O., Foglia, T.A. Haas, M.J., Okpefa, J.E. and Obibuzor, J.U. (2000). Lipase-Catalyzed Production of Biodiesel Fuel from Nigerian Lauric Oils, Biochem. Soc. Trans. 28(3): 979-981.

[17] Eevera, T.; Balamurughan, P.; and Chittibabu .S. (2011). Characterization of groudnut oil based biodiesel to assess the feasibility for power generation. Energy Sources, Part A. J. 33 1354-1364.

[18] Okoro N. Linus, Sedoo V. Belaboh, Nwamaka R. Edoye, Bello Y. Makama (2011): Synthesis, Calorimetric and Viscometric Study of Groundnut oil Biodiesel and Blends. Research Journal of Chemical Sciences, 1(3).

[19] Yusuf N. and Sirajo, M. (2009). An Experimental Study of Biodiesel Synthesis from Groundnut Oil, Aus. J. Applied Sci., 3: pp. 1623-1629.

[20] Saravanan, S., Nagarajan, G., Rao, G. L. N. and Sampath, S. (2007): Feasibility study of crude rice bran oil as a diesel substitute in a DI-CI engine without modifications, Energy for Sustainable Development, 11(3): 83- 95.

[21] Biomass Research and Development Board (2008). The economics of biomass feedstocks in the United States: A review of the literature. Retrieved from 
http://www.biodiesel.org/ on October 12, 2008.

[22] Ahmmad, M.; Ullah, K.; Khan, M.A.; Zafari, M.; Tariq, M.; Ali, S. \& Sultana. S. (2011). Physico chemical analysis of hemp biodiesel: A Promising non edible new sources for bioenergy. Energy Sources, Part A. J. 33 1365-1374.

[23] Geller, D.P., Goodrum, J.W. and Campbell, C.C. (1999). Rapid Screening of Biologically Modified Vegetable Oils for Fuel Performance, Trans. ASAE, 42(4) 859-862.

[24] Chavanne, C.G. (1938). Belgian Patent 422,877, Aug. 31, 1937; Chem. Abs. 32:4313.

[25] Freedman, B., Butterfield, R.O. and Pryde, E.H. (1986). Transesterification Kinetics of Soybean oil, Journal of the American Oil Chemists Society, 63(10): pp. 1375-1380.

[26] Diesel, R. The Diesel Oil-Engine and Its Industrial Importance Particularly for Great Britain, Proc. Inst. Mech. Eng. pp. 179-280 (1912); Chem. Abstr. 7(1): pp. 1605 (1913).

[27] Canakci, M. and Gerpen, V.J. (2001). Biodiesel Production from Oils and Fats with High Free Fatty Acids, Transactions of the ASAE, 44(6): pp. 1429-1436.

[28] Shay, E.G. (1993). Diesel Fuel from Vegetable Oil: Status and Opportunities, Biomass Bioenergy, 4(4): pp. 227-242.

[29] Lang, X., Dalai, A.K., Bakhshi, N.N., Reaney, M.J. and Hertz, P.B. (2001). Preparation and Characterization of Bio-diesels from Various Bio-oils, Bioresource Technology, 80(4): pp. 53-62.

[30] Okamura, K. Substitute Fuels for High-Speed Diesel Engines, Journal. Fuel Soc. Japan, 19(1): pp. 691-705 (1940); Chem. Abstract 35: 19647 (1941).

[31] Ma, F., Clements, L.D. and Hanna, M.A. (1998). The Effects of Catalyst, Fatty Acids and Water on Transesterification of Beef Tallow, Transactions of the ASAE, 41(4): 1261-1264.

[32] Sambo, A.S. (2007). Renewable Energy Development in Nigeria: A Situation Report. In: Proceedings of the International Workshop on Renewable Energy Development in Africa, July 30th to August 1st, University of Nigeria, Nsukka, 1-39.

[33] Ford, G.H. (1921). Vegetable Oils as Engine Fuel, Cotton Oil Press 5: pp. 38; Chem. Abstract 15: 3383.

[34] Korbitz W., (1999). Biodiesel Production in Europe and North America, an Encouraging Prospect, Renew Energy 16(2): 80-83.

[35] Lumet, G. and Marcelet, H. (1927). Utilization of Marine Animal and Fish Oils (as Fuels) in Motors, Compt. Rend. 185: pp. 418-420; Chem. Abstr. 21: 27-37.

[36] Sanchez, O.J. and Cardona, C.A. (2008). Trends in Biotechnical Production of Ethanol Fuel from Different Feedstocks, Bioresour. Technol., 37(2): 133-140

[37] Dalai A.K \& Kulkarni, M.G. (2006). Waste cooking oil-an economical source for biodiesel: A review. Industrial \& Engineering Chemistry Research. J. 45 2901-2913.

[38] Ahmad, M.; Samuel, S.; Zafari, M.; Khan, M.A.; Tariq. M.; Ali. S. \& Sultana. S. (2011). Physicochemical characterization of eco-friendly rice bran oil biodiesel. Energy, Part A. J. 33 1386-1397.

[39] Durosoy, I.; Turker, M. F.; Keles, S. \& Kaygusuz, K. (2011). Sustainable agriculture and the production of biomass for energy use. Journal of Energy Sources, Part A, 33, 938-947.

[40] Hamamci, C.; Saydut, A.; Tonbul, Y.; Kaya, C. \& Kafadari, A.B (2011). Biodiesel production via transestarification from safflower (Carthemustinctorious L) seed oil. Energy Sources Part A. J. 33 512-520. 
[41] Pearl, G.G. (2002). Animal Fat Potential for Bioenergy Use, Bioenergy, The Tenth Biennial Bioenergy Conference, Boise, ID, Sept. 22-26.

[42] Evans, C.D., Moser, H.A., Cooney, P.C., Cowan, J.C. (1966). The Stability of Soybean Oil: Effect of Time and Temperature on Deodorization, JAOCS, 43(2): 632-634.

[43] U.S. Department of Agriculture (2009). Data on Groudnut oil. Retrieved from http://www.nal.usda.gov/fnic/foodcomp/search/ on April 22, 2011.

[44] Abulu, G.O. (1978). An Economic Analysis of Groundnut Production in Northern Nigeria. In: Proceedings of the National Seminar on Groundnut Production, Kano, Nigeria. pp. 83-90.

[45] Hill, P.D., (2002). Biodiesel Basics. Retrieved from http://www.biodieselgear.com/ on August $16^{\text {th }}, 2002$. 7-10.

[46] AOCS (1998). Official Methods and Recommended Practices of the American Oil Chemists Society. Champaign, IL

[47] Ibeto, C.N., Ofoefule, A.U. and Ezeugwu, H.C. (2011). Fuel Quality Assessment of Biodiesel Produced from Groundnut Oil (Arachis hypogea) and its Blend with Petroleum diesel, American Journal of Food Technology, 6(9): 798-803.

[48] Al-zahrani, K.M. (2005). Determination of saponification number in olive oil. 14(3) pp13-27

[49] Othmer, K. (2011). Castor Oil: Encyclopedia of Chemical Technology. Retrieved from http://www.castoroil.in on 25th June, 2011.

[50] Pasqualino, J. C., Montane, D. and Salvado, J. (2006). Synergic Effects of Biodiesel in the Biodegradability of Fossil-Derived Fuels, Biomass Bioenergy, 30(2): 874-879.

[51] Anitha, A. and Dawn, S.S. (2010). Performance characteristics of biodiesel produced from waste groundnut oil using supported heteropolyacids, International Journal of Chemical Engineering and Applications, Vol.1, No. 3, 261-265.

[52] Freedman, B., Butterfield, R.O. and Pryde, E.H. (1986). Transesterification Kinetics of Soybean oil, Journal of the American Oil Chemists Society, 63(10): 1375-1380.

[53] Galadima, A., Garba. Z.N. and Ibrahim, B.M. (2008). Homogeneous and Heterogeneous Transesterification of Groundnut Oil for Synthesizing Methyl Biodiesel, International Journal of Pure and Applied Sciences, 2(3): 138-144.

[54] Graboski, M.S. and McCormick, R.L. (1998). Combustion of Fat and Vegetable Oil Derived Fuels in Diesel Engines, Prog. Energy Combust Sci., 24(3): 125-164.

[55] Gunstone, F.D. (2004). Rapeseed and Canola Oil: Production, Processing, Properties and Uses, JAOCS, 33: 132-139.

[56] Pintoa, A. C., Guarieiroa, L. L. N., Rezendea, M. J. C., Ribeiroa, N. M., Torresb, E. A., Lopesc, W. A., Pereirac, P. A. P. and Andrade, J.B.(2005): Biodiesel: An overview, J. Braz. Chem. Soc., Vol. 16, No. 6B, 1313-1330.

[57] Dorado, M.P., Ballesteros, E., Lopez, F.J. and Mittelbach, M. (2004). Optimization of Alkali-Catalyzed Transesterification of Brassica carinata Oil for Biodiesel Production, Energy Fuel, 18(2): 77-83. 